Georgia State University

ScholarWorks @ Georgia State University

World Languages and Cultures Faculty

Publications

Department of World Languages and Cultures

2016

\title{
Building social capital alongside a strong sense of efficacy
}

Peter Swanson

Georgia State University, peters@tribcsp.com

Terry Osborne

University of South Florida Sarasota-Manatee, terryosborn@sar.usf.edu

Follow this and additional works at: https://scholarworks.gsu.edu/mcl_facpub

Part of the Other Languages, Societies, and Cultures Commons

\section{Recommended Citation}

Swanson, Peter and Osborne, Terry, "Building social capital alongside a strong sense of efficacy" (2016). World Languages and Cultures Faculty Publications. 52.

https://scholarworks.gsu.edu/mcl_facpub/52

This Article is brought to you for free and open access by the Department of World Languages and Cultures at ScholarWorks @ Georgia State University. It has been accepted for inclusion in World Languages and Cultures Faculty Publications by an authorized administrator of ScholarWorks @ Georgia State University. For more information, please contact scholarworks@gsu.edu. 


\section{FL Annals President's Message Summer Issue}

Title: Building social capital alongside a strong sense of efficacy.

By Pete Swanson, Ph.D. and Terry A. Osborn, Ph.D.

As I mentioned in the January/February 2016 issue of The Language Educator, building a strong sense of efficacy in teaching languages (i.e., our confidence) is a very important part of being successful in the classroom. If we have the mindset that we have the ability to bring about desired outcomes of student engagement and learning, even among those students who may be difficult or unmotivated, there are a myriad of benefits for our students as well as ourselves. As new teachers enter classrooms, it is important to help them build and sustain a strong belief that they can effect positive change in the classroom and remain in the classroom. As I discussed in the last issue of Foreign Language Annals, there is a critical shortage of certified language teachers in the United States (US), an issue ACTFL takes seriously.

To that end, I invited Dr. Terry A. Osborn, Vice Chancellor for Academic and Student Affairs at the University of South Florida Sarasota-Manatee, to collaborate on this article to discuss the recruitment of highly effective language teachers. For years Dr. Osborn has helped prepare preservice language teachers and is an authority on academic achievement. During our discussions about recruiting and retaining the next generation of highly effective language teachers, we feel that teacher preparation programs will benefit from including goals related to social and academic integration. That is, in order to succeed in college, students, especially those from disadvantaged backgrounds, need to have academic and social support which will facilitate adaptive mindsets to both understand the challenges they will experience in college and to learn how they can overcome these obstacles in order to be successful academically.

For example, if a college student starts feeling like a visitor landing in an alien country, like US Supreme Court Justice Sonia Sotomayor recounted (Ludden \& Weeks, 2009), negative outcomes become apparent, both socially and academically. Working in a similar fashion to one's sense of efficacy, if pre-service language teachers begin to feel that they are not college material, a negative self-fulfilling prophecy begins to emerge and students begin to doubt their abilities. As doubts set in, they begin to withdraw from the learning environment, not taking advantage of the tutoring or other support services available, ultimately experience lower achievement, and give up when impediments to success arise. Research indicates that these individuals become less likely to reach out to faculty members for assistance, join student groups, and even seek out friends (Logel, Murphy, Walton, \& Yeager, n.d). The same research showed that well-developed interventions during key transition points can assuage feelings of not belonging and can influence lasting improvements.

When recruiting students in high school to consider teaching languages as a profession, especially those who are first generation college students, mindset interventions hold promise. For example, by having older pre-service language teachers visit high school language classes (e.g., French), adolescents can learn more about collegiate life and its challenges and learn firsthand how to overcome obstacles as well as more about the teacher preparation curriculum. In short, these future college students must be able to visualize themselves in college, and as 
successful. Therefore, it is important for teacher preparation programs to foster in their teacher candidates a sense of social belonging because research shows that it is related to long-term student motivation and school success (Logel et al., n.d.). Individuals who who feel like they belong in college have better relationships with instructors, "are more motivated and engaged in class and earn better grades, effects that hold in spite of what their prior levels of motivation and performance might have been (Furrer \& Skinner, 2003; Wentzel, 1997). In short, they develop social capital (e.g., close friendships, development of mentor relationships) and are more successful in their academic and personal pursuits.

Thus, if we can help our future language teachers develop a sense of belonging in college as well as a strong sense of efficacy in teaching languages, we are more likely to build and sustain a population of highly effective language teachers.

\section{References}

Furrer, C., \& Skinner, E. (2003). Sense of relatedness as a factor in children's academic engagment and performance. Journal of Educational Psychology, 95, 148-162.

Logel, C., Murphy, M., Walton, G., \& Yeager, D. (n.d). College transition collaborative. Available from, scl.cornell.edu/sites/sas.cornell.edu/files/.../College_Transition.pdf

Ludden, J., \& Weeks, L. (2009, May 26). Sotomayor: Always looking over my shoulder. NPR. Available from, http://www.npr.org/templates/story/story.php?storyId=104538436

Wentzel, K. R. (1997). Student motivation in middle school: The role of perceived pedagogical caring. Journal of Educational Psychology, 89, 411-419. 